\title{
DEDICATION \\ fOR VICTOR HASSINE
}

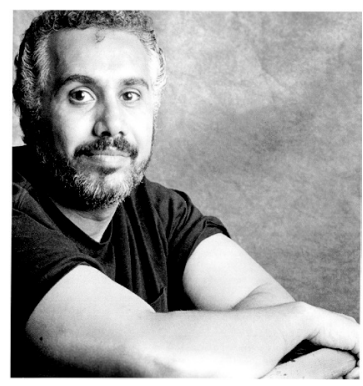

1955-2008

Photo by Howard Zehr (1996)

$\mathrm{V}$

ictor Hassine completed an undergraduate degree in political science and history in 1977. He graduated from New York Law School in 1980. In June 1981, he was convicted of homicide in Pennsylvania and sentenced to life without parole. Victor found his voice as a writer and playwright while incarcerated at Graterford, Pennsylvania.

I never thought to be a writer, I never thought that I would find myself in a position to have to write. I never thought that I would have to be a person who was a chronologist. But all that changed when I came to prison and I suddenly found myself immersed in misery... not only my own misery, but misery that people had experienced... Prison is just one tragedy after another, and you have to express it somehow. Some people express it through anger. I chose at some point to express it through writing. (JPP, 1999, p. 107).

Victor contributed the first of seven essays to the Journal of Prisoners on Prisons in 1993 (Volume 5, Number 1), when I became the editor. As our friendship deepened, Victor sent me a wealth of his writing; short stories, plays, and his marvellous ethnographic analysis of prison culture and life. Having studied prison literature and worked with prison writers for decades, I was taken by the quality of his writing and the depth of his understanding. Victor's keen observation and extraordinary detachment was in the tradition of the best ethnography and I marvelled at his ability to read the prison from within the "belly of the beast".

...so when I write about prison I don't want to write what you already know, what 9,000 textbooks are written about... I want you 
to read it. I want you to understand prison better, not as a cliché, but as a real life experience (JPP, 1999, p. 118).

So in order for me to write from the outside, I just placed myself to a point that I was before I came to prison, and I ask myself what would I have seen, what would I not have wanted to see. You have to detach yourself. The hardest thing in the world is for a person who wants to help the poor to have to live amongst the poor. You see so much misery... So what I do is I detach myself and I have to or else I would have so much hate because being crammed in this prison, in these small cells with so many angry and hurt people, injured people, makes you hate, and you can't write objectively with all that hate in you. And so part of my pleasure in writing is that in order to write objectively I have to remove myself from prison. And although I don't remove myself from prison physically, my mind is removed and I'm a little more free, I'm a little less hateful, and I can better deal with it. (ibid, pp. 119-120).

Victor established himself as one of the world's premier prison writers. Life Without Parole: Living in Prison Today (1996) is now in its fourth edition and has been widely used as a text for university courses. He was exceptionally pleased that his fictional work was published in The Crying Wall and Other Prison Stories (2005). His play Circles of Nod (1996) won a PEN Award and was read at the Edward Albee Theatre Conference in 1999. A prolific writer and chronologist, Victor's work was widely published in academic journals and texts. He was also an activist who used his legal education to file successful suits against the Pennsylvania Department of Corrections over living conditions.

Victor's writing mapped the vast changes that occurred in the USA prison-industrial complex over the past quarter century. Essays, such as "Monochromes From Over a Prison's Edge" (Hassine, 1998), place him in the pantheon of great prison writers with Victor Serge, Jean Genet and François Villon. On March 31, 1999, Victor held a teleconference with a seminar class I taught at the University of Ottawa. He opened as follows:

This poem was written from the Bastille, where Villon reflected upon the executions he could observe from his cell window, and his own pending death. 


\section{"Ballade des pendus"}

Freres humains qui apré nous vivez

N'ayez les cuers contre nous endurcis

Car, se pitie de nous povres avez

Dieu en aura plus tost de vous mercis.

Vous nous voiez cy attachez cinq, six :

Quant de la chair, que trop avons nourrie,

Elle est pieca devoree et pourrie,

Et nous, les os, devenons cendre et pouldre.

De nostre mal personne ne s'en rie

Mais priez Dieu que tous nous vueille

Absouldre!
Brother Men who after us live on, harden not your hearts against us, for if you have some pity on us poor men,

the sooner God will show you mercy.

You see us, five, six, strung up here: as for our flesh, which we have fed too well,

already it has been devoured and is rotten,

and we, the bones now turned to dust and ashes.

Let no one laugh at all our miseries, but pray to God that He absolve us all!

And basically I stand where François Villon stands, and I understand now better than ever the need for mercy, not for mercy's sake but for all our sake (JPP, 1999, pp. 105-106).

Bob Gaucher

\section{REFERENCES}

Gaucher, Bob (1999) “An Interview with Victor Hassine", Journal of Prisoners on Prisons, 10(1\&2): 105-127.

Hassine, Victor (1998) "Monochromes From Over a Prison's Edge", Journal of Prisoners on Prisons, 9(2): 55-69.

Hassine, Victor (1996) Life Without Parole: Living in Prison Today, Los Angeles: Roxbury Publishing Company.

Hassine, Victor (1993) “The Man Who Didn't Do It", Journal of Prisoners on Prisons, 5(1): 4-13.

Hassine, Victor (unpublished) Circles of Nod.

Hassine, Victor, Robert Johnson and Ania Dobrzanska (2005) The Crying Wall and Other Prison Stories, West Conshohocken (PA): Infinity Publishing Company.

Zehr, Howard (1996) Doing Life: Reflections of Men and Women Serving Life Without Parole, Intercourse (PA): Good Books. 